\title{
Discourse of Children in William Blake's “Chimney Sweeper
}

\author{
Nujhat Afrin
}

\begin{abstract}
This study of the poems, present a contradiction between the states of innocence and experience, two phases through which all people must pass. Here we see the naturalistic world of childhood against the world of corruption. The poem "The Chimney Sweeper" is set against the dark background of child labor that was well known in England in the late $18^{\text {th }}$ and $19^{\text {th }}$ century. The poems (Chimney Sweeper in innocence and Experience) are meant to convey two different views of human life, the view of innocence and the view of experience. In the state of innocence, we look at things freshly; we look at natural objects and wonder at them, finding in them a child's simple apprehension of beauty. Blake writes these poems to let the reader knows that many kid's lives are being exploited in the cities of England. He expresses his disgust about the plight of the majority of the chimney sweepers and how the society and church turn a blind eye of their sufferings. In the society they live in, innocent children are in anguish because of the harsh treatment of the adult population. While it endorses hope, the reader must acknowledge that something needs to be done to improve the lives of these children.
\end{abstract}

i. History of poetry for children: Between the years 1715 and 1804, no genuine poems for infant minds were written. In 1715 Isaac Watts had written "Divine and Moral songs in Easy Language" which is a book of short poems intended for children. But in the following years there was no prolific writing for children. After Watts there were Ann and Jane Taylor, but they were chiefly the creators of the moral tale in verse. However there are three writers who stand out as separate figures in the period 1715-1804. They made verses about children and for children. The three are John Merchant, Nathaniel Cotton and William Blake.

At first William Blake was unknown to the younger minds of that period. But later, Blake's poems surpassed all the barriers of negligence and lack of consideration and secured a prominent place in the world of verses for children. Blake's "Songs of Innocence" is a record of the innocent experience, an expression of human nature which is observed and conceived by a child. And at its root lies the ecstasy of shadowless and pure joy. Blake's "Songs of Innocence and Experience" published in one volume in 1724. Songs of Innocence and Experience are collections of lyrics in which there are many pair's of poems. The tone and the mood of the first section that is, the "Songs of Innocence" is struck in the first poem "Introduction" itself. In the first series the poet gives expression to the gleeful aspects of childhood and their sports. But as it comes nearer to the more serious aspect of "Experience", the poem gathers complex imageries and symbols.

ii. The chimney sweepers are in a sense destitute since their parents sell them to sweep the soot. The soot that sticks on their body is so choking that the boy in his dream views it as a coffin. As Freud says, "Children see their unfulfilled desires of real life as fulfilled in dreams and that very thing happens here. The little boy's sense of "father-lessness" and lack of parental care hurt him and so he dreams of the possibility of having a father who may be kind, protecting and warmly hearted. But later when he turns back to the reality of daylight, he realized that if everyone does their duty patiently then they need not to fear harm. Actually this study explores that unsatisfactory mind of children and the wrong judgment of society with them.

While Blake writing his second series of poems "Songs of Experience", he included several reflections of poems which were a part of his "Songs of Innocence". The two sides of the story, innocence and experience bear many differences in their presentation of the chimney sweeper's views and attitudes and also in the way Blake has portrayed each of them. Songs of Innocence opens with the child like voice of the chimney sweeper. The first words of the poem seem to contradict it's categorization as innocent, mentioning a mother's death. Blake's view in the second line that reinforces this feeling as the child was sold by his father when very young. But the parents of the sweeper in the Experience are still alive, but have gone to the Church to pray. However, the experience version begins by describing the boy as "A little black thing", dehumanizing him completely. The fact that he stands "among the snow" is a great contrast to his appearance. The snow is also symbolic of bleakness and death surrounding the child and possibly also the cold, uncaring world in which he lives.

iii. At the age of four and five, boys were sold to clean chimneys, due to their small size. It was not extraordinary sight to see the children sweeping the soot of chimneys even when fire was burning below in the fire place. It was these inhuman activities that led Blake to write this poem. "The Chimney Sweeper" by William Blake reveals a plead for social justice. In "The Chimney Sweeper "from Innocence, there is an immense contrast between the death, weeping, exploitations and oppression that Tom Dacre endures and his childlike innocence that enables him to be native about his grave situation and the widespread injustice in society. Tom Dacre's imagination takes him on a lovely journey with his ultimate hope of being nurtured and 
cared for by his Father in Heaven. William Blake creates sympathy and sharp awareness for Tom Dacre, who represents other neglected children in poverty, by introducing his personal tragedy at the beginning of the poem. Tom Dacre's innocence is being forcibly stolen from him. His sacrificial life to society is emphasized as William Blake shares a narrative of Tom Dacre's hair that symbolizes lamb's hair, is shaved off. Even deeper the lamb symbolizes the Christian theme of Christ's purity. The middle of the poem brings heartful smiles for the children and the children filled with laughter and happiness. The poem also throws light upon the miserable life of young children who are subject to inhuman treatment in the society of industrialized England. Though the poet finds society indifferent to the miseries of young boys, he is sure that in the hands of God they will be treated kindly. Blake portrays greedy fathers who sell their children for a few pounds and abandon them to the eternal hell of suffering. Since the chimneys were too narrow only small children were employed as chimney sweeps. Generally all the laborers of the factories suffered from the unhealthy atmosphere of the factories. They were treated like animals. They had to wake up in the night and go on sweeping until noon. They put their soot in their soot bags and came out like little black spirits. At home they slept on poor beds and were feed poorly. They were paid very poorly and nobody thought of their health. Tom's dream is a realistic picture of his life. The coffin of soot in which he saw his fellow workers locked up is nothing but the coating of soot that stuck on their body when they came out after sweeping the chimney. The term "coffin" also suggests the danger of death that lurked in the work the little boys did. Tom dreams that the sweeps are shut up and locked in a black coffin but they are not locked up for ever. The angel with bright keys liberates them and they began to play and revel in the air. Here also their innocence is preserved with the help of God. Like the "little black boy" who suffers injustice on earth but get justice in heaven, the chimney sweepers also suffer much on earth but will be free to sport on clouds when they are liberated by the angel. In this study we see that Tom's dream makes him hope that a wonderful life awaits for him. His faith in God is so strong that it becomes his only constant source of hope and inspiration. In a sense this last stanza is not just a conclusion but a separate stanza of it's own, because Tom's desperate desire for freedom and life. The optimistic outlook, which is real to Tom, is revealed to be unrealistic on earth.

The pure innocence of children and the heavenly, secure and gleeful pastoral works of sport and merrymaking is seen in "Innocence" which Blake deals with. In this section, we see the children enjoying unbridled freedom; they play until they are satisfied. They speak to animals like lambs and sheep which are as innocent as themselves. It is a heaven that lies about their infancy. The unstained world of innocence also provides them guardian angels for ensuring their security. Blake is not exclusively unconcerned with the evil practices in the society against children. The little black boy and the chimney sweeper lament their lots. But what differentiates them from the world of experience is that, at the end of all such poems that give expression to the hostility of the society. Blake brings the children out of the fold of this vicious circle and restores them to the heavenly abode of God. Blake's view also brings in this theory of God-God as child and lamb. Thus God, lamb and child form a trinity. Here the images he draws are simple, commonplace and pastoral. He fills the scenes of Innocence with angels who talk to children and mingled with them. In "Innocence" we hear the "wren-like-warbling" echoing in the green fields and gardens. The pastoral setting is sunny, full of flying and warbling birds and ringing sonorous bells. The problem of these songs lies in their peculiar naivety. This is not the simplicity has of childhood, of incomplete experience; this simplicity has it's origin in no experience at all. Blake's condemnation of the "perishing vegetable memory" as a substitute for inspiration, and his preference of the "Eternal Image" to the actual object are both relevant here.

The symbolism and pictorial beauty is textured by the warp and woof. In his poems the lamb is a symbol of God. "The Echoing Green" is not merely the depiction of a merry day; it is a symbolic presentation of the "Day of Innocence" from sunrise to sunset. "Infant Joy", "The Little Black Boy" and "Laughing Song" symbolize the three ages of Innocence- infancy, childhood and youth. "A Cradle Song", "Nurse's Song" and "Holy Thursday" are symbolic of the same three ages of man. This time in relation to society and the remaining poems, which image the human soul in it's quest of self realization, are all of even deeper symbolic import.

iv. The two sections of Blake's book, the "Songs of Innocence" and "Songs of experience" are contrasted elements in a single design. The first part sets out an imaginative vision of the state of innocence. The second shows how life challenges and corrupts and destroys it. In the World of experience what we find is not the stainless atmosphere of heart-felt joy and innocence; instead it obscures the state of childlike innocence and sets up many detrimental forces in its place. To show the measure of this harassment Blake has incorporated in the "Songs of Experience" some poems which furnish utter contrasts to their counterparts which are in the Songs of Innocence. In "Nurse's Song" the poet recounts how children play and are permitted to go on playing until it is almost night and time to go to bed. The symbolic significance of this piece becomes more and more curious when we came to know that, by this Blake means the care-free play of human imagination when it is not spoiled by senseless imagination. But it is strikingly the opposite in the realm of the "Songs of Experience". The voice that now speaks is not that of pure affection rather we hear of sour and bitter age, envious of festivities and freedom which it can no more share. It teases the children, hinting at the closing darkness and sees plays as a whiling away of time. The first and most fearful thing about experience is that, it scatters and deranges the 
imaginative life and puts in it's place a dark, cold and deterring frightful concern and anxiety. In a majority of the cares repression, jealousy, cruelty and loveless ness are the dominant elements. In experience even the parents seem to be indifferent to the sufferings of their children. They sell them for a few pennies and leave them to work as chimney sweeps. In a similar way, the boy that is delivered into this world is felt as a burden by its parents. In the sphere of Experience the human heart becomes a "pebble of the book", and turns love into an insincere and selfish desire of lust of profession.

In "Songs of Experience" the child lays all the blame for his condition on his parents, which is understandable as children in their fully dependent state, naturally view their parents as virtually all powerful. A child chimney sweeper abandoned in the snow, while his parents were in Church. In this study of the poem, here in the first stanza an observer comes upon not a child, but "A little black thing among the snow". And it is indicating that, innocent corrupted by something evil. Blake's target is not parents who force their children to work, but rather the rich and powerful who exploit the poor and weak. The King enjoys his wealth and comfort at the expense of his subjects. The Priest enjoys his work. And God as creator, ultimately is responsible for this unjust world. As the child is abused by his parents, indirectly they also abused by "God and his Priest and King". Thus Blake condemns the injustice of both late $18^{\text {th }}$ century British society and a world in which such injustice is allowed to exist. The sweeper's parents are really no help towards their own child. If they are worshipping god, the source of good doings, why do they chose to ignore their own child. Thus would rather turn their heads the other way and instead find love at church. In this study we find also irony in the first stanza, when the chimney sweeper in his black shroud of soot. The color black seems to be very important because it is used to represent sin against innocence, the color of the white snow. At such an early stage of life children are privileged to have the tender care of their mother and father. But such essential loving care is denied to the chimney sweeper. The duty of parents is to protect the children from harm and troubles. But here the parents of the chimney sweeper neglect their child and go to pray. Even the clothes that the parents provided for the child are the clothes of death and not any protective covering. As the child has done no injury, the parents go to worship God and praise the priest and king who make a heaven out of the miseries of the child.

Following the study, there is imagery in both poems. In Songs of Innocence, the child says, "in soot I sleep". This could mean that the boy did not have any other clothes and had to sleep in his ashy clothes, or it could mean that he was so tired that he actually fell asleep on the job. There is also imagery in the use of names. In the "Songs of Innocence" poem, names such as Tom, Dick, and Joe are used because the boy is a lighthearted and seems to have friends in the business. It makes the child seem as if he does not view chimney sweeping as a terrible job. However in the Songs of Experience poem, no names were mentioned giving the idea that this child sweeper does not view the job as hanging with his friends. It feels more like an imprisonment type situation, not as light and playful. This contrast is not so much seen in the individual poems, but in a comparison of the two.

In this study found an interesting similarity between the two poems is the use of the spoken words "weep! Weep!". This was the cry of the chimney sweepers trade. However, it also bears connotations to weeping or crying. This is emphasized in both poems, in experience through saying "in notes of woe" and in innocence through "could scarcely cry". This indicates the poor situation of the boy between the two contradictory states of the human soul, innocence and experience. In the study of the innocence, we found further links to it's nature are created. The use of a real name "Tom Dacre", a device rarely used by Blake, establishes a more personal relationship between the sweeper and the reader. Once again a feeling of pity is created as the study serve that, Tom's hair "That curl'd like a lamb's. was shav'd". The lamb in this line is a symbol that Blake uses for pure innocence, showing Tom to be a pure. "soot can not spoil your white hair", this presents a further link to the experience version, through the use of the color white. Here however, it can be taken to symbolize purity and divinity rather than the cold harsh conditions. Blake's view in the next three stanzas of the innocence poem describes the vision had by Tom while he was asleep. Tom sees thousand of sweepers locked up in coffins of black. Again, this does not seem to fit with Blake's usual style for innocence poems. However the "locked" coffins of "black" reinforce the feelings of doom. This contrasts with the "bright key" the angel uses to unlock the coffins. Suddenly the innocent nature of the poem becomes more apparent, through the use of an angel. The final stanza of this dream again linking to the ideas of not only purity but also the Bible, in which Adam and Eve are unashamed to be without clothes before their fall from grace. This reinforces the core theme of innocence. This reinforces the core theme of innocence. The angel then speaks directly to Tom, explaining that providing he is good, he would "have God for his father and never want joy". This is a great idea for a parentless child to look forward to, even though these happy thoughts may only come true in death. This darker idea underlies the poem, echoing the ideas of religion that whatever hardships you face now, everything will be better in death. The final idea of the poem also hints at this idea of "if all do their duty, they need not fear harm".

v. Blake has portrayed two very different ideas by describing the situation of a chimney sweeper. Both versions agree that the life of the child on the earth is dismal and unfulfilling, in a cruel and uncharitable world, portrayed through Blake's use of symbolism. His Songs of Experience presented a very dark and pessimistic world. This poem also seems to be very judgemental and gives motives for everything, but unlike Songs of 
Innocence, the sweeper in this poem does not free himself from his misery. Here Blake also criticizing the Church. During this time many children were dying from being, either, worked to death or from malnutrition. Neither the state nor the church did anything to stop this and is obviously why Blake feels so much anger towards them. The sweeper's parents were not careful about their children. The study found us that, if they are worshipping God, the source of good doings, why do they close to ignore their own child. They would rather turn their heads the other way and instead find love at church. In his Songs of Innocence Blake suggests that there is a life after death which will make up for the chimney sweeper's hardship, encouraging him to stay positive. The study of the "Songs of Experience" explore to us as a very striking poem. It clearly shows Blake's anger toward's society at this time. He used many of his poems to make people aware of the suffering of people at this time. This study also presents that, Blake wrote two separate books to give a fuller effect. Through this study, Songs of Innocence was how people thought that everything was okay. And Songs of Experience was to open every one's eyes.

\section{References}

[1] Speak Silence: Rhetoric and Culture in Blake's Poetical Sketches. Ed. Mark L. Greenberg. (Wayne State Univ Press, 1996).

[2] William Blake: Poet and Painter. Jean H. Hagstrum. (University of Chicago Press, 1964).

[3] William Blake: His Life and Work. Jack Lindsay. (Constable, 1978)

[4] The Stranger from Paradise: A Biography of William Blake. G. E. Bentley, Jr. (Yale Univ Press, 2003). 